\title{
Evaluation of saliva as a biochemical indicator for electrolyte estimation in sickle cell anaemic patients
}

\author{
Dr. Kavita A Madan ${ }^{1}$, Dr. Sudhindra Baliga $\mathrm{M}^{2}$, Dr. Nilima Thosar ${ }^{3}$, \\ Dr. Sachin Khatri ${ }^{4}$, Dr. Nilesh Rathi ${ }^{5}$ \\ ${ }^{1}$ (MDS.Department of Pedodontics and Preventive Dentistry, Sharad Pawar Dental College and Hospital, \\ Wardha, Maharashtra, India) \\ ${ }_{2}^{2}$ (Professor and Head, Department of Pedodontics and Preventive Dentistry, Sharad Pawar Dental College and \\ Hospital, Wardha, Maharashtra, India) \\ ${ }_{3}^{3}$ (Professor, Department of Pedodontics and Preventive Dentistry, Sharad Pawar Dental College and Hospital, \\ Wardha, Maharashtra, India) \\ ${ }^{4}$ (Assistant Professor, Dept of Public Health Dentistry, Government Dental College and Hospital, Nagpur, \\ Maharashtra, India) \\ ${ }_{5}^{5}$ (Reader, Department of Pedodontics and Preventive Dentistry, Sharad Pawar Dental College and Hospital, \\ Wardha, Maharashtra, India)
}

\begin{abstract}
:
Background: Sickle cell anaemia, a type of haemoglobinopathy is associated with biochemical abnormalities such as imbalance of electrolytes.

Aim: To determine and evaluate saliva as a biochemical indicator for electrolyte estimation in sickle cell anaemic patients.

Materials and methods: 30 children in the age group of 4-12 years were split into two equal groups: sickle cell anaemia group and control group. $2 \mathrm{ml}$ of blood and unstimulated salivary sampleswere collected aseptically and assayed to determine the values of Sodium ( $\mathrm{Na}+$ ), Potassium ( $\mathrm{K+})$, Calcium $(\mathrm{Ca}++)$ and Chloride $(\mathrm{Cl}--)$ using ABL 800 Flex Analyzer and XundaXd 600 electrolyteanalyzer.

Results: A significantly higher level of sodium \& chloride was found in serum as compared to the saliva of sickle cell patients, while the mean level of potassium \& calcium was found to be significantly lower in serum. The levels of serum sodium and potassium amongst sickle cell patients were significantly higher as compared to healthy children, while serum calcium level was found to be significantly lower among sickle cell patients.

Conclusion: Biochemical abnormality plays a significant role in sicklecell patient's physiopathology and can be used to managementof the disease. Electrolyte estimation using saliva has been proven to be a potential noninvasive biomarker for electrolyte estimation in sickle cell anaemic patients.
\end{abstract}

Keywords: Children, Electrolytes, Saliva, Serum, Sickle cell anaemia,

\section{Introduction}

Haemoglobinopathies are a group of inherited disorders that results in the synthesis of either a globin chain with an abnormal structure or reduced synthesis of a globin chain with normal structure leading to chain imbalance. Sickle cell anaemia, a type of haemoglobinopathy is a group of hemoglobin disorders that occurs because of mutation in beta globulin gene of hemoglobin molecule, that leads to formation of abnormal hemoglobin designated as hemoglobin $\mathrm{S}(\mathrm{HbS}){ }^{[1]}$ It is one of the most commonly observed haemoglobinopathies affecting millions of people in the world and poses a significant challenge for clinicians and scientists. The sickle shaped red blood cells cannot carry as much oxygen as normal shaped cells to the tissues and they become stuck in the blood vessels, blocking blood flow to the organs. This is seen more commonly in India, especially in scheduled tribes and scheduled castes as compared to other endogamous groups. ${ }^{[2]}$ As this disorder is recessive in nature, the heterozygotes are absolutely asymptomatic but the homozygotes suffer from serious complications leading to short life span. ${ }^{[3]}$

Biochemical abnormalities related with imbalance of electrolytes have been associated with sickle cell anaemia.Electrolytes are nothing but the substances that become ions in solution and acquire the capacity to conduct electricity. Various studies involving sickle cell patients have shown that there are increased and continued obligatory losses of body fluids and electrolytes resulting in dehydration and other metabolic disturbances. ${ }^{4}$ Thus a proper balance of electrolytes in the body is essential for the normal functioning of the cells and organs. Electrolytes measured by blood testing includes sodium $(\mathrm{Na}+)$, potassium $(\mathrm{K}+)$, chloride $(\mathrm{Cl}-)$, calcium $(\mathrm{Ca}++)$ and bicarbonate (HCO3-) ${ }^{[4]}$ Any significant change in the electrolyte levels leads to serious complications. Thus, a proper functioning of body requires a proper balance between these electrolytes. ${ }^{[4,5]}$ 
Sodium forms one of the major positive ion commonly found in the fluid present outside of the cells. ${ }^{[1]}$ Its main function being regulation of the amount of total body water along with its critical role in electrical communication especially in the brain, nervous systems and muscles. Potassium is the major positive ion that is commonly found in the interior of the cells. The proper level of potassium is necessary for normal cell function. Among the many functions of potassium in the body are regulation of the heart beat and function of the muscles. Dehydration in sickle cell anaemia patients results in sodium as well as chloride and other electrolyte imbalance leading to sickling, sequestration and haemolysis.A normal level of calcium in the body is required for proper functioning of the skeletal system. The role of calcium homeostasis as it affects pathological changes in the skeletal system in sickle cell disease has recently attracted attention. ${ }^{[6]}$

In biochemical analysis, serum has been a gold standard.However, the role of saliva in investigations is considered as a potential analytical mediator due to its noninvasive nature of collection. This factor makes saliva a substitute anda more practical diagnostic tool. Hence, this study was aimed to evaluate the role of saliva in the estimation of electrolytes in sickle cell anemic patients.

\section{Study Design}

The study protocol was approved by the institutional ethical committee. A total of 30 children between the age group 4 to 12 years were selected,out of which 15 were suffering from sickle cell anemia attending the clinics atAcharayaVinobhaBhave Rural Hospital and remaining 15 were healthy children who reported to SharadPawar Dental College for their routine dental checkup who served as controls from whom the saliva and blood sampleswere taken. Children with any other systemic diseases,immunocompromised children andchildren having past 3 months of vasoocclussive crisis, blood transfusion and serious illness were excluded from the study.

Informed written consent was taken from parent/guardian accompanying the child patient. Blood and saliva samples were collected aseptically from the patient. The collected samples were processed for estimationof sodium, potassium, chloride and calcium electrolytes.

\section{Collection of blood sample}

Patient was asked to sit comfortably on the chair. The tourniquet was applied in arm and the antecubital fossa was cleaned with cotton swab soaked in spirit. $2 \mathrm{ml}$ of blood was withdrawn from the cubital vein with 24 gauge needle. Blood was transferred to plain sterile bulb which was kept undisturbed for half an hour at room temperature. Supernatant was removed and centrifuged at $3000 \mathrm{rpm}$ for 4-5 minutes. Serum obtained was stored at $-20^{\circ} \mathrm{C}$ in refrigerator till further processing.

\section{Collection of saliva sample}

Subjects were instructed not to eat or drink except water for at least one hour before the sample collection to minimize diurnal variation. For collection of the sample, patient was asked to sit comfortably for five minutes with eyes open and head tilted down slightly. Saliva was allowed to accumulate in the floor of the mouth without swallowing and then the patient was asked to spit it into sterile plastic plain tubes. These samples were kept in freezing box and stored at $-20^{\circ} \mathrm{C}$ in refrigerator till further processing. The values of Sodium (Na+), Potassium (K+), Calcium $(\mathrm{Ca}++)$ and Chloride $(\mathrm{Cl}--)$ in centrifuged blood and saliva were evaluated using ABL 800 Flex Analyzer (Radiometer America Inc) andXunda Xd 600 electrolyte analyzer (Xunda Medical Instrument Co). ABL 800 Flex analyzer (Radiometer America Inc ) was used to estimate the values of sodium and chloride ions, while the potassium and calcium ions were estimated using Xunda XD Electrolyte Analyzer (Xunda Medical Instrument Co).

\section{Results}

The SPSS 16.0 software was used for statistical analysis and the results were obtained. Difference in various parameters between the two groups were analysed for significance using Mann Whitney's test. Statistical significance was defined as $\mathrm{P}<0.05$.

Mean ages of the patients in sickle cell anemia group were $9.9 \pm 2.60$ years and that of the control were $9.57 \pm 2.27$ years by using unpaired students t test. However no statistical significant difference was found in the ages of patients of both the groups $(\mathrm{p}>0.05)$ [Table 1].

Sickle cell anemia group was composed of $6(40 \%)$ males and $9(60 \%)$ females. Gender distribution occured by chance and it did not represent the sickle cell anaemia distribution according to gender. Moreover control group was composed of 10 ( 64.3\%) male and $5(35.7 \%)$ female children. No statistical significant difference was observed in the gender of the patients of both the groups according to chi square test $(\mathrm{p}>0.05)$ [Table 1] 
A significantly higher level of sodium \& chloride was found in serum as compared to the saliva of sickle cell patients. The mean level of potassium \& calcium was found to be significantly lower in serum as compared to the saliva in sickle cell patients [Table 2].

There was significantly higher levels of serum sodium and potassium amongst sickle cell patients as compared to healthy children, while serum calcium level was found to be significantly lower among sickle cell patients. There was no significant difference in serum chloride, salivary sodium, potassium, chloride and calcium levels between sickle cell patients and healthy children[Table 3].

A moderately positive and significant correlation was found between serum and salivary sodium and potassium, while there was a weak positive and non-significant correlation between serum and salivary chloride and calcium [Table 4].

\section{Discussion}

The balance of electrolytes in the body is essential for the normal functioning of the cells and organs. Various biochemical manifestations of sickle cell disease are well documented in the literature and the possible roles that these manifestations play in the pathophysiology of the disease have been proposed. ${ }^{[3]}$ Dehydration commonly occurring in sickle cell anemia patients leads to electrolyte imbalance that promotes sickling, sequestration and haemolysis of red blood cells.Inthe past, serum has been utilized for the biochemical investigations of electrolytes in sickle cell anaemia patients. Hence, this study was aimed to evaluate the role of saliva as a tool for estimation of these electrolytes. ${ }^{[1,4]}$

The results of the present study showed that a significant higher level of sodium was found in serum as compared to the saliva in sickle cell anaemia patients. This was in accordance with the results given by Agoreyo et al who stated that dehydration of the sickle cells is known to cause an increase in the cationic permeability of sodium ions which could be an important factor in increasing the sodium ion concentration. ${ }^{[1]}$ Similarly chloride was found to be significantly higher in serum as compared to saliva in sickle cell group. The increase in chloride ion concentration may be attributed to an abnormal activation of potassium chloride $(\mathrm{K}+\mathrm{Cl}-)$ co transport system as suggested by Vitoux et al in $1989 .{ }^{[10]}$ Also, the major determinant of sickle cell dehydration is the potassium chloride transporter which is inhibited in sickle cell anaemia patients that may result in reduction of absolute reticulocyte count and the number of immature reticulocytes. ${ }^{[11]}$

In the present study, the mean level of potassium was found to be significantly lower in serum as compared to saliva of patients suffering from sickle cell anaemia. Hyponatremia observed in sickle cell anemia was attributed to dehydration as suggested by Brugnara (2000). ${ }^{[3]}$ The loss of potassium is also associated with calcium activated potassium channel in kidneys. ${ }^{[12]}$ Tosteson et al concluded that deoxygenation of sickle RBCs increasedcation permeability leading to significant net potassium loss and sodium gain. ${ }^{[6]}$

Homeostasis is affected in sickle cell disease ${ }^{[7,8]}$ The mean level of calcium was lower in serum of sickle cell anaemia patients as compared to saliva of the same patients. A tendency towards hypocalcaemia in sickle cell anaemia patientswas found in our study, which was similar to the results concluded by Muhammed S etal. ${ }^{[13]}$ The complex nature of calcium homeostasis and the roles of vitamins and hormones lead to the fact that patients with sickle cell disease are not universally hypocalcaemic. Deoxygenation of sickle cell is known to increase cation permeability of calcium. ${ }^{[7]}$

A significant higher level of serum sodium and potassium were found amongst sickle cell patients as compared to healthy children, while serum calcium level was found to be significantly lower among sickle cell patients. No significant difference was observed in serum chloride, salivary sodium, potassium, chloride and calcium levels between sickle cell patients and healthy children.

Although blood is considered as a gold standard for the biochemical investigations in the field of medical sciences, it is not particularly convenient for children being an invasive procedure. The procedure for collection of saliva is simple, non-invasive, easy to store, and inexpensive as compared to blood collection. Theelectrolytes that can be measured in the blood can be easily measured in the saliva due to the development of nanotechnology, which has allowed researchers to handle substances at an atomic scale.In addition to these advantages, saliva collection offers a painless alternative, eliminating the stress that the patient can feel which can be useful for paediatric, geriatric and medically compromised patients.

TABLES

Table 1: Comparison of baseline parameters between sickle cell patients $\&$ healthy children

\begin{tabular}{|l|l|l|l|}
\hline & SICKLE PATIENTS $(\mathbf{n}=15)$ & HEALTHY CONTROLS $(\mathbf{n}=15)$ & P- VALUE \\
\hline AGE & $9.9(2.60)$ & $9.57(2.27)$ & 0.88 \\
\hline SEX & $40 \%$ & $35.7 \%$ & 0.83 \\
FALE & $60.0 \%$ & $64.3 \%$ & \\
\hline
\end{tabular}


Evaluation of saliva as a biochemical indicator for electrolyte estimation in sickle cell anaemic..

Table 2: Comparison of serum \& saliva electrolytes in sickle cell patients

\begin{tabular}{|l|l|l|l|}
\hline & Serum & Saliva & $\mathrm{p}^{*}$ Value \\
\hline $\mathrm{Na}$ & $113.25(27.35)$ & $27.60(12.10)$ & $\mathbf{0 . 0 0 5}$ \\
\hline $\mathrm{K}$ & $5.72(0.88)$ & $16.52(4.76)$ & $\mathbf{0 . 0 0 5}$ \\
\hline $\mathrm{Cl}$ & $87.3(30.79)$ & $34.10(12.16)$ & $\mathbf{0 . 0 0 5}$ \\
\hline $\mathrm{Ca}$ & $4.79(2.88)$ & $5.17(0.46)$ & $\mathbf{0 . 0 0 5}$ \\
\hline
\end{tabular}

*. Wilcoxon signed rank test

Table 3: Comparison of serum \& saliva electrolytes between sickle cell patients \& healthy children

\begin{tabular}{|l|l|l|l|}
\hline & Sickle patients $(\mathrm{n}=$ & Healthy children $(\mathrm{n}=$ & $\mathrm{p}$ * Value \\
\hline Serum Na & $113.25(27.35)$ & $138.43(18.87)$ & $<\mathbf{0 . 0 1}$ \\
\hline Serum $\mathrm{K}$ & $5.72(0.88)$ & $4.58(0.49)$ & $\mathbf{0 . 0 0 4}$ \\
\hline Serum Cl & $87.30(30.79)$ & $110.0(8.56)$ & 0.056 \\
\hline Serum Ca & $4.79(2.88)$ & $5.17(0.46)$ & $<\mathbf{0 . 0 1}$ \\
\hline Saliva Na & $27.60(12.10)$ & $24.57(9.16)$ & 0.43 \\
\hline Saliva K & $16.52(4.76)$ & $18.70(3.71)$ & 0.25 \\
\hline Saliva Cl & $34.10(12.16)$ & $36.64(13.11)$ & 0.70 \\
\hline Saliva Ca & $1.09(0.19)$ & $1.03(0.29)$ & 0.58 \\
\hline
\end{tabular}

*-mannwhitney U test

Table 4: Spearman's Correlation between serum \& saliva electrolytes in sickle cell patients

\begin{tabular}{|l|l|l|l|l|}
\hline & Saliva Na & Saliva K & Saliva Cl & Saliva Ca \\
\hline Serum Na & $0.68^{*}$ & & & \\
\hline Serum K & & $0.71^{*}$ & & \\
\hline Serum Cl & & & 0.32 & \\
\hline Serum Ca & & & & 0.41 \\
\hline
\end{tabular}

\section{Conclusion}

Saliva has been used as a biomarker for evaluating the salivary biochemistry ofmany diseases. In the present study both saliva and serum are used for the estimation of various biochemicals in the body. There is a correlation between the electrolytes estimated from salivary and serum samples. Hence it could be concluded that saliva can be an efficient noninvasive biomarker for investigation of electrolytes in sickle cell anemia patient.

\section{References}

[1]. Agoreyo FO, Nwanze N, Plasma sodium and potassium changes in sickle cell Patients, International Journal of Genetics and Molecular Biology,2, 2010,014-019.

[2]. Urade BP, Haemoglobin S and $\beta$ Thal: Their Distribution in Maharashtra, India, International Journal of Biomedical Sciences, 9, 2013, 75-81.

[3]. Gupta V, Singh AK, Saha J, Nigam P, Baburaoa SK, Singh N, Variation in serum electrolyte in sickle cell patients in chhattisgarh population. International Journal of Science Innovations and Discoveries, 2, 2012,239-243.

[4]. Pandey S, Sharma A, Biochemical Indicator of Sickle Cell Disease, Preliminary Report from India, Ind J ClinBiochem, 27, 2012,191-195.

[5]. Oladipo OO, Temiye EO, Ezeaka VC, Obomanu P, Serum, magnesium, phosphate and calcium in Nigerian children with sickle cell disease, West Afr J Med, 24, 2005,120-3.

[6]. Tosteson DC, Shea E, Darling RC, Potassium and sodium of red blood cells in sickle cell anemia, Journal of Clinical Investigation,31, 1952,406-411

[7]. Nduka N, Kazem Y, Saleh B, Variation in serum electrolytes and enzyme concentrations in patients with sickle cell disease, Journal of Clinical Pathology,48, 1995,648-651.

[8]. Al-Dabbagh AA, Acquaye JK, Al-Baghdadai TM, El- Zamzamy MM, Radiological bone changes of sickle cell anaemia in Western Saudi Arabia, Saudi Med J,10,1989,367-71.

[9]. Rathod S, Brahmankar R, Oral Health Status in Sickle Cell Anemia Subjects, Journal of Dental and Medical Sciences,6, 2013,2528.

[10]. Vitoux D, Olivieri O, Garay RP, Cragoe EJ Jr., Galacterous F, Bevizard Y, Inhibition of K+ efflux and dehydration of sickle cells by [(Dihydroindenyl)oxy] alkanoic acid: an inhibitor of the K+-Cl- co transport system, Proc. Natl. Acad. Sci. U. S. A.,86, 1989,4273-4276.

[11]. Ndefo UA, Maxwell AE, Chiobi TL, Pharmacological Management of Sickle Cell Disease, Journal of Pharmacy and Therapeutics,33, 2008,238-243.

[12]. Clark MR, Guatell JC, White AT, Shohet SB, Study of the dehydrated effect of the red cell Na+/K+ pump in treated cells with varying $\mathrm{Na}+$ and water content, Biochem. Biophys. Acta.,646,1981,422-432.

[13]. Muhammed S, Addae S, Suleiman S, Adzaku F, Annobil S, Kaddoumi 0, et al., Serum calcium, parathyroid hormone and vitamin D status in children and young adults with sickle cell disease, Ann ClinBiochem,30, 1993,45-51. 